\title{
Soupis prací Stanislavy Kloferové
}

(č) článek, studie, (d) drobnost, (h) heslo ve slovníku, (k) kapitola v knize, (m) monografie, (pp) popularizační přednáška, (ps) popularizační stat', (r) recenze, (s) stat' v ČJA, (z) zpráva

1983

1. (z) ORLOVSKÝ, Jozef. Stredogemerské nárečia. Jazykovědné aktuality 20, 1983, 115-116.

\section{4}

2. (ps) Zvykneme si na nové prostředí? Rovnost, Brno 28.1.1984.

\section{5}

3. (ps) Budeme cestovat do Jeseníku a Šumperku? Rovnost, Brno 22. 2. 1985.

4. (ps) Trápit se úlohou i s úlohou. Rovnost, Brno 29. 11. 1985.

\section{6}

5. (r) ŠToLC, Jozef. Atlas slovenského jazyka II. Flexia. Bratislava 1978-1981. Sborník prací Filozofické fakulty brněnské univerzity A 34, 1986, 148-150.

\section{7}

6. (r) Kniha o dichotomii spisovnosti a nespisovnosti v českém národním jazyce. (CHLOUPEK, Jan. Dichotomie spisovnosti a nespisovnosti, Praha 1987). Naše řeč 70, 1987, 1, 40-44.

7. (č) O mluvě mladé generace v nově osídleném severomoravském pohraničí. Naše řeč 70, 1987, 5, 237-248.

8. (ps) Volejbalové ohlédnutí. Rovnost, Brno 10. 4. 1987.

\section{8}

9. (ps) Znáte kudlibabku? Rovnost, Brno 29. 4. 1988.

10. (ps) Vincek s honzíkem. Rovnost, Brno 11. 11. 1988.

\section{9}

11. (ps) O šmoulování, a nejen o něm. Rovnost, Brno 23.12. 1989.

1990

12. (č) Nářeční pojmenování plodů lopuchu v češtině. Naše řeč 73, 1990, 5, 235-241.

13. (č) O vývoji dialektismů v severomoravském pohraničí. Sborník prací Filozofické fakulty brněnské univerzity A 37-38, 1990, 142-148. 


\section{1-1992}

14. (č) Deantroponymická pojmenování malých kamínek v češtině. Onomastický zpravodaj ČSAV 32-33, 1991-1992, 38-40.

\section{2}

15.-20. (5+1 s) Český jazykový atlas 1. Praha: Academia, 1992. Dotisk: Praha: Academia, 2004. Členka autorského kolektivu, 5 statí samostatných (položky 8, 38, 107, 172, 179), 1 stat' spolu s Věrou Lamprechtovou-Michálkovou (položka 43).

21. (č) K nářeční nivelizaci. In: BuzÁssyová, Klára, ed. 1992. Varia I. Slovenská jazykovedná spoločnost' pri SAV, 82-85.

\section{4}

22. (č) O názvech německého původu v české nářeční zemědělské terminologii. Naše řeč 77, 1994, 4, 179-185.

23. (č) K německým výpůjčkám v nářečích. Slovo a slovesnost 55, 1994, 3, 202-207.

24. (ps) Sliby chyby. Rovnost, Brno 18.11. 1994, 8.

25. (ps) Vídeň neznámá I. Rovnost, Brno 22. 7. 1994, 8.

26. (ps) Vídeň neznámá II. Rovnost, Brno 29. 7. 1994, 8.

27. (ps) Vídeň neznámá III. Rovnost, Brno 19. 8. 1994, 8.

\section{5}

28. (č) Co nového v pohraničí? Čeština doma a ve světě 4, Moravský blok, 1995, 256-258.

29. (č) Adaptace slov cizího původu v českých nářečích. In: KARLík, Petr - Pleskalová, Jana - Rusínová, Zdenka, eds. 1995. Pocta Dušanu Šlosarovi. Boskovice: Albert, 118-122.

30. (č) K fungování jazykových útvarů v mluvě mládeže. In: JANčÁkovÁ, Jana - KomÁREk, Miroslav - UličnÝ, Oldřich, eds. 1995. Spisovná čeština a jazyková kultura 1993. Praha: FF UK, 104-105.

31. (r) Česká Vídeň. (Monika Glettler, Böhmisches Wien). Naše řeč 78, 1995, 5, 257-260.

32. (z) Pleskalová, Jana. Tvoření pomístních jmen na Moravě a ve Slezsku. Čeština doma a ve světě 4, Moravský blok, 1995, 279-280.

\section{6}

33. (č) Ta, či ten sršeň? (K rodovým dubletám v češtině). Naše řeč 79, 1996, 4, 187-191.

34. (č) Nářeční slovní zásoba a status spisovnosti. In: ŠRÁMEK, Rudolf, ed. 1996. Spisovnost a nespisovnost dnes. Brno: Masarykova univerzita, 142-144.

35. (č) Deutsche Sprachreflexe in der tschechischen Lexikographie. In: BREMER, Ernst HildebrandT, Reiner, eds. 1996. Stand und Aufgaben der deutschen Dialektlexikographie. Historische Wortforschung 4. Berlin - New York: Walter de Gruyter, 49-56.

36. (pp) Nad Českým jazykovým atlasem. In: Rusınová, Eva, ed. 1996. Přednášky a besedy z XXIX. běhu LŠSS. Brno: Masarykova univerzita, 43-46.

\section{7}

37. (20 s) Českýjazykový atlas 2. Praha: Academia, 1997. Členka autorského kolektivu, 20 statí (položky 18, 21-22, 32, 52, 75, 86, 118, 132, 134-135, 142, 145, 147, 153, 161-162, 169, 179-180).

38. (k) Běžná mluva v severomoravském pohraničí. In: DANEš, František et al. 1997. Český jazyk na prelomu tisíciletí. Praha: Academia, 250-255. 


\section{8}

39. (č) Jak dnes mluví mladí vídeňští Češi I. Naše řeč 81, 1998, 2-3, 61-72.

40. (č) Jak dnes mluví mladí vídeňští Češi II. Naše řeč 81, 1998, 4, 169-178.

41. (pp) K současné české dialektologii. In: Rusinová, Eva, ed. 1998. Přednášky a besedy z XXXI. běhu LŠSS. Brno: Masarykova univerzita, 43-49.

42. (č) Zum Problem der Synonymie im Tschechischen anhand des Tschechischen Sprachatlasses. In: GROSSE, Rudolf, ed. 1998. Bedeutungserfassung und Bedeutungsbeschreibung in historischen und dialektologischen Wörterbüchern: Beiträge zu einer Arbeitstagung der deutschsprachigen Wörterbücher, Projekte an Akademien und Universitäten vom 7.-19. März 1996 anläßlich des 150jährigen Jubiläums der Sächsischen Akademie der Wissenschaften zu Leipzig, Philologisch-historische Klasse, Bd. 75, Hf 1. Stuttgart - Leipzig: S. Hirzel Verlag, 197-198.

\section{9}

43.-70. (28 s) Český jazykový atlas 3. Praha: Academia, 1999. Členka autorského kolektivu, 28 statí (položky 31-36, 52, 54-55, 57, 65-66, 84-90, 94, 98, 111, 182, 210, 213, 228, 229-230).

71. (m) U nás ve Vídni. Vídeňští Češi vzpomínají. Brno: Masarykova univerzita ve spolupráci s Ústavem pro jazyk český AV ČR, 1999, 149 s. (spolu s Janem Balharem a Jarmilou Vojtovou)

72. (č) Die Struktur der Benennung im Sprachkontakt. In: TATZREITER, Herbert - HoRNUnG, Maria - ERnst, Peter, eds. 1999. Erträge der Dialektologie und Lexikographie. Festgabe für Werner Bauer zum 60. Geburtstag. Wien: Edition Praesens, 289-302.

73. (č) Mluva mladé generace vídeňských Čechů. Estetika 36 (1-3), Kultura českých enkláv ve světě), 1999, 155-159.

\section{0}

74. (m) Mluva v severomoravském pohraničí. Brno: Masarykova univerzita, 2000. $130 \mathrm{~s}$.

75. (č) Vlastní jména v Českém jazykovém atlase. Naše řeč 83, 2000, 1, 10-16.

76. (č) Areálová lingvistika, etymologie a štastné dřevo. In: JANYšKová, Ilona - KARLÍkovÁ, Helena, eds. 2000. Studia etymologica Brunensia 1. Praha: Euroslavica, 277-282.

77. (d) Zombi(e), ale mumie. Naše řeč 83, 2000, 2, 104-105.

78. (č) Nářečí v kontaktu. In: KARLík, Petr - HLADKÁ, Zdenka, eds. 200o. Čeština - univerzália a specifika 2. Brno: Masarykova univerzita, 47-52.

79. (̌̌) Die Sprache der Wiener Tschechen. Forschungsstand und Ausblick. Wiener Slavistisches Jahrbuch 46, 2000, 107-115.

\section{1}

80. (č) Přehláska 'a > e v lexikálních svazcích Českého jazykového atlasu. Naše řeč 84, 2001, 4, 171-174.

81. (r) Kolik tváří má čeština. (BogoczovÁ, Irena - CHLoupEK, Jan - JANDovÁ, Eva - KRčMovÁ, Marie - Müllerová, Olga. Tváře češtiny. Ostrava 2000). Naše řeč 84, 2001, 5, 261-265.

82. (r) BogoczovÁ, Irena - CHLOUPEK, Jan - JANdovÁ, Eva - KrčMovÁ, Marie - MÜLlerovÁ, Olga. Tváře češtiny. Ostrava 2000. Wiener Slavistisches Jahrbuch 47, 2001, 262-266.

2002

83.-122. (40 s) Českýjazykový atlas 4. Praha: Academia, 2002. Členka autorského kolektivu, 40 statí (položky 53-56, 59-66, 71-81, 402-417, 424). 
123. (h) Atlas jazykový. In: Karlík, Petr - Nekula, Marek - Pleskalová, Jana, eds. 2002. Encyklopedický slovník češtiny. Praha: Nakladatelství Lidové noviny, 48-50.

124. (h) Dialekt. In: KARLík, Petr - Nekula, Marek - Pleskalová, Jana, eds. 2002. Encyklopedický slovník češtiny. Praha: Nakladatelství Lidové noviny, 109-110.

125. (h) Dialektologie. In: KARLík, Petr - Nekula, Marek - Pleskalová, Jana, eds. 2002. Encyklopedický slovník češtiny. Praha: Nakladatelství Lidové noviny, 110.

126. (h) Dotazník. In: Karlík, Petr - Nekula, Marek - Pleskalová, Jana, eds. 2002. Encyklopedický slovník češtiny. Praha: Nakladatelství Lidové noviny, 116-117.

127. (h) Enkláva českého jazyka. In: KARLík, Petr - NEkula, Marek - Pleskalová, Jana, eds. 2002. Encyklopedický slovník češtiny. Praha: Nakladatelství Lidové noviny, 124-126. (spolu s Janem Balharem a Milenou Šipkovou)

128. (h) Hranice nářeční. In: Karlík, Petr - Nekula, Marek - Pleskalová, Jana, eds. 2002. Encyklopedický slovník češtiny. Praha: Nakladatelství Lidové noviny, 170-171.

129. (h) Izoglosa. In: Karlík, Petr - Nekula, Marek - Pleskalová, Jana, eds. 2002. Encyklopedický slovník češtiny. Praha: Nakladatelství Lidové noviny, 189.

130. (h) Jádro nářečí. In: KARLík, Petr - NEkUlA, Marek - Pleskalová, Jana, eds. 2002. Encyklopedický slovník češtiny. Praha: Nakladatelství Lidové noviny, 191.

131. (h) Krátkost moravská. In: Karlík, Petr - Nekula, Marek - Pleskalová, Jana, eds. 2002. Encyklopedický slovník češtiny. Praha: Nakladatelství Lidové noviny, 236-237. (spolu s Janem Balharem)

132. (h) Metoda jazykovězeměpisná. In: KARLík, Petr - NekulA, Marek - Pleskalová, Jana, eds. 2002. Encyklopedický slovník češtiny. Praha: Nakladatelství Lidové noviny, 261262.

133. (h) Nářečí přechodová. In: Karlík, Petr - Nekula, Marek - Pleskalová, Jana, eds. 2002. Encyklopedický slovník češtiny. Praha: Nakladatelství Lidové noviny, 279.

134. (h) Proteze. In: Karlík, Petr - Nekula, Marek - Pleskalová, Jana, eds. 2002. Encyklopedický slovník češtiny. Praha: Nakladatelství Lidové noviny, 348-349. (spolu s Radoslavem Večerkou a Dušanem Šlosarem)

135. (h) Skupina nářeční. In: KARLík, Petr - Nekula, Marek - Pleskalová, Jana, eds. 2002. Encyklopedický slovník češtiny. Praha: Nakladatelství Lidové noviny, 392-393.

136. (h) Skupina nářeční východomoravská. In: KARLík, Petr - NEkULA, Marek - PleskALovÁ, Jana, eds. 2002. Encyklopedický slovník češtiny. Praha: Nakladatelství Lidové noviny, 401-404.

137. (h) Zeměpis jazykový. In: Karlík, Petr - Nekula, Marek - Pleskalová, Jana, eds. 2002. Encyklopedický slovník češtiny. Praha: Nakladatelství Lidové noviny, 564-565.

\section{3}

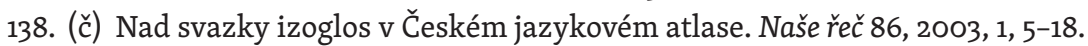

139. (č) Český jazykový atlas: neznámé nářeční areály. Sborník prací Filozofické fakulty brněnské univerzity A 51, 2003, 203-212.

140. (č) Areálová lingvistika a sémantické tvoření slov. In: JANYšKovÁ, Ilona - KARLÍkovÁ, Helena, eds. 2003. Studia etymologica Brunensia 2. Praha: Nakladatelství Lidové noviny, 365-376. 
141. (pp) Český jazykový atlas. In: RusinovÁ, Eva, ed. 2003. Přednášky a besedy z XXXVI. běhu LŠSS. Brno: Masarykova univerzita, 66-72.

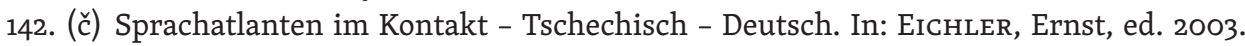
Selecta Bohemico Germanica. Tschechisch-deutsche Beziehungen im Bereich der Sprache und Kultur. LIT Verlag, Münster - Hamburg - London, 39-53.

143. (č) Sprachareale und ihr Charakter bei der Erforschung von Sprachkontakterscheinungen. Anhand des Tschechischen Sprachatlasses. In: Greule, Albrecht - Nekula, Marek, eds. 2003. Deutsche und tschechische Dialekte im Kontakt. Wien: Edition Praesens, 21-36.

\section{4}

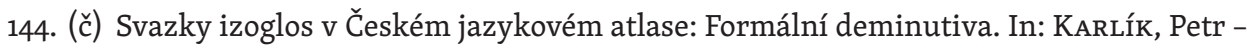
PleskalovÁ, Jana, eds. 2004. Život s morfémy. Sborník studií na počest Zdenky Rusínové. Brno: Masarykova univerzita, 101-109.

145. (č) K morfologickým moravismům. In: MináŘová, Eva - ONDRÁšKovÁ, Karla, eds. 2004. Spisovnost a nespisovnost. Zdroje, proměny a perspektivy. Brno: Masarykova univerzita, 50-54.

146. (r) Menzel, T., Hentschel, G.: Wörterbuch der deutschen Lehnwörter im Teschener Dialekt des Polnischen. Oldenburg 2003. Kritikon Litterarum 31, 2004, 1/2, 55-57.

\section{5}

147.-149. $(2 s+k)$ Český jazykový atlas 5. Praha: Academia, 2005. Členka autorského kolektivu, 2 stati (položky 294-295) + kapitola Svazky izoglos v nářečích (448.1-462.4) s 15 mapovými listy.

150. (č) K počátkům dialektologie na Moravě. In: ČMEJRková, Světla - SvoBodová, Ivana, eds. 2005. Oratio et ratio. Sborník k životnímu jubileu Jiř́ho Krause. Praha: Ústav pro jazyk český AV ČR, 191-196.

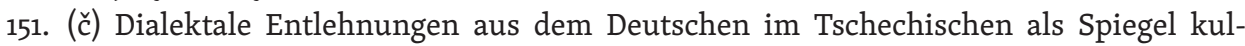
tureller Beziehungen (Dialektale Areale und Sprachkontakterscheinungen). In: HAusner, Isolde - Wiesinger, Peter, eds. 2005. Deutsche Wortforschung als Kulturgeschichte. Wien: Verlag der Österreichischen Akademie der Wissenschaften, 275286.

152. (h) Nářečně různorodá oblast. In: DokoupiL, Lumír - MYŠKA, Milan - SvobodA, Jiří, eds. 2005. Kulturněhistorická encyklopedie Slezska a severovýchodní Moravy II (N-Ž). Ostrava: Repronis, 23-25.

153. (d) Vy neznáte rýsováček? Naše řeč 88, 2005, 4, 217-220.

154. (pp) Jak se mluví na Moravě? In: Rusinová, Eva, ed. 2005. Přednášky a besedy z XXXIII. běhu LŠSS. Brno: Masarykova univerzita, 66-72.

\section{6}

155. (k) Vídeňská čeština? Das Wiener Tschechisch? In: BASLER, Helena - BRANDEIS, Marie - Kroupa, Jiř́ K. - StAREK, Jana, eds. 2006. Die Wiener Tschechen 1945-2005. Zur Geschichte einer Volksgruppe / Vídeňští Češi 1945-2005. K dějinám národnostní menšiny. Band/Svazek 1. Wien - Praha: Tschechisches kulturhistorisches Institut / České kulturněhistorické centrum, 191-206, 421-433. 
156. (k) Nářečí. In: ONDRÁčKovÁ, Milada - STALMACH, Ladislav, eds. 2008. Vír v údolí Svratky. Vír: Obec Vír, 160-164.

157. (č) Český jazykový atlas a výzkum běžné mluvy aneb Co máme a co nemáme. Naše řeč 89 , 2006, 1, 11-14.

158. (č) Vy neznáte Cajzla? (K původu a významu přezdívky). Naše řeč 89, 2006, 191-197.

159. (č) Areálová lingvistika: Svazky izoglos ve službách etymologie. In: JANYŠKová, Ilona KARLíková, Helena, eds. 2006. Studia etymologica Brunensia 3. Praha: Nakladatelství Lidové noviny, 143-148.

160. (č) Bartošova Dialektologie moravská a Český jazykový atlas. In: PRUDKÁ, Alena - UHLíková, Lucie, eds. František Bartoš, dialektolog, pedagog, etnograf. Konference $k 100$. výročí úmrtí. Sborník z konference, Zlín 25.-26. dubna 2006. Acta musealia Muzea jihovýchodní Moravy ve Zlíně, suplementa, 2006, 1, 27-31.

161. (č) Grenzen der Sprachgrenzen. In: HöHNE, Steffen - NEkula, Marek - Tvrdík, Milan - Cvrkal, Ivan, eds. 2006. Brücken. Neue Folge 13. Germanistisches Jahrbuch. Tschechien - Slowakei 2005. Praha: Nakladatelství Lidové noviny, 47-58.

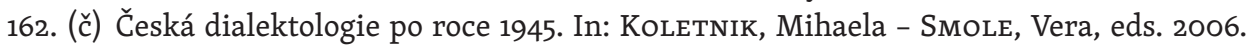
Diahronija in sinhronija $v$ dialektoloških raziskavah. Zora 41. Maribor: Slavistično društvo, 62-69.

2007

163. (k) Dialektologie. In: PleskAlovÁ, Jana - KRČMová, Marie - VeČERKA, Radoslav - KARLÍK, Petr, eds. 2007. Kapitoly z dějin české jazykovědné bohemistiky. Praha: Academia, 336-376.

164. (č) Spitznamen im Kontakt. In: Muzikant, Mojmír, ed. 2007. Deutsche Dialekte in Tschechien, ihre Gemeinsamkeiten und Besonderheiten im Vergleich zum Mutterboden. Beiträge zu einem internationalen Symposium an der Masaryk-Universität, 26. bis 27. Januar 2006. Brno: Masarykova univerzita, 127-133.

165. (z) Konference František Bartoš, dialektolog, pedagog a národopisec (Zlín 25.24. 4. 2006). Českýlid 94, 2007, 1, 71-72.

166. (mapa) Jak se kde mluví. Nářečí v České republice. Lidové noviny 258, 20, 5. 11. 2007, příloha Čeština v práci. (spolu s Libuší Čižmárovou a Milenou Šipkovou)

2008

167. (č) K nepřeneseným víceslovným pojmenováním v nářečích. In: ČoRNEjovÁ, Michaela Kosek, Pavel, eds. 2008. Jazyk a jeho proměny. Prof. Janě Pleskalové k životnímu jubileu. Brno: Host, 110-120.

168. (č) Česká dialektologie ve slovanském kontextu. Česká slavistika. Příspěvky k XIV. mezinárodnímu sjezdu slavistů, Ochrid 10.-16. 9. 2008. Slavia 77, 2008, 93-103.

169. (č) Die Semantik im Sprachkontakt. In: PонL, Heinz Dieter, ed. Akten der 10. Arbeitstagung für bayerisch-österreichische Dialektologie (Klagenfurt, 19.-22. September 2007), Klagenfurter Beiträge zur Sprachwissenschaft 34-36, 2008-2010, 194-204.

2009

170. (k) Nářečí na Boskovicku. In: VÁLKA, Miroslav, ed., a kol. 2009. Lidová kultura a nářečí na Boskovicku. Vlastivěda Boskovicka. Svazek 2. Boskovice: Muzeum Boskovicka v nakladatelství Albert, 293-311. 
171. (č) Basy a housle $\mathrm{v}$ onomastice a dialektologii (Příspěvek $\mathrm{k}$ dialektologii pomístních jmen). In: HARVALík, Milan - MinÁŘovÁ, Eva - TušKová, Jana Marie, eds. 2009. Teoretické a komunikační aspekty proprií. Brno: Masarykova univerzita, 237-245.

172. (̌̌) Propriale und nichtpropriale Sprachareale: Einheit in der Vielfältigkeit. Slavia Centralis 3, 2010, 52-60.

173. (r) VojtovÁ, Jarmila. Slovník středomoravského nářečí horského typu, Masarykova univerzita, Brno 2008, 279 stran. Linguistica Brunensia 57, 2009, 306-309.

\section{0}

174. (k) Mapping the Slavic languages. In: LAmeli, Alfred - KeHrein, Roland - Rabanus, Stefan, eds. 2010. Language and Space. An International Handbook of Linguistic Variation. Volume 2. Language Mapping. Berlin - New York: De Gruyter, Part I 317-333, Part II Maps \# 1501-1511.

175. (č) Pomístní jména odvozená od osobních jmen v kontextu onomastickém a dialektologickém. Acta onomastica 51, 1, 2010, 106-139.

\section{1}

176. (m) Český jazykový atlas. Dodatky. Praha: Academia, 2011. Členka autorského kolektivu.

177. (č) K územnímu rozrůznění předložek v pomístních jménech na Moravě a ve Slezsku. Acta onomastica 52, 1, 2011, 92-101.

178. (h) Dušek, Vavřinec Josef. In: VošAHLíková, Pavla a kol. 2011. Biografický slovník českých zemí. Dot-Dvo. Praha: Libri, sešit 14, 450-451.

179. (č) Onymický a dialektový areál: paralelnost, či identičnost? In: HoLuB, Zbyněk - SuKAČ, Roman, eds. 2011. Dialektologie a geolingvistika v současné střední Evropě. Frýdek-Místek: Kleinwächter ve spolupráci se Slezskou univerzitou v Opavě, 164-172.

180. (pp) Čeština a její dialekty: Český jazykový atlas a Slovník nářečí českého jazyka. In: RuSINovÁ, Eva, ed. 2011. Přednášky a besedy ze XLIV. běhu LŠSS. Brno: Masarykova univerzita, 102-108.

2012

181. (č) Český jazykový atlas a čeština. In: ČmEJRkovÁ, Světla - HofFMANNová, Jana - KLÍMovÁ, Jana, eds. 2012. Čeština $v$ pohledu synchronním a diachronním. Stoleté kořeny Ústavu projazyk český. Praha: Karolinum, 297-302.

182. (č) K dialektologickým aspektům české onymie. In: SiERociuk, Jerzy, ed. 2012. Gwary Dziś 6. Aktualne problemy dialektologii słowiańskiej. Práce Komisiji Dialektologicznej przy Międzynarodowym Komitecie Slawistów. Poznań: PTPN, 145-154.

2013

183. (č) Současná česká dialektologie: po Českém jazykovém atlasu Slovník nářečí českého jazyka. Slavia 82, 2013, 1-2, 169-174.

184. (h) Ertl, Václav. In: MAKARIUsová, Marie, ed. 2013. Biografický slovník českých zemí. EpFe. Praha: Libri, sešit 16, 20-21.

185. (pp) Překážet, nebo zavazet? K nářečním jevům v soudobé češtině. In: Rusinová, Eva, ed. 2013. Přednášky a besedy ze XLVI. běhu LŠSS. Brno: Masarykova univerzita, 93-99. 


\section{4}

186. (k) Hádky o Hádky. In: MináŘová, Eva - Sochorová, Dagmar - ZítKová, Jitka, eds. 2014. Vlastníjména $v$ textech a kontextech. Brno: Masarykova univerzita, 122-126.

187. (r) Nářeční kontakty německo-české ve třetím tisíciletí (k výzkumu historických německých nářečí v České republice). Slovo a slovesnost 75, 2014, 2, 127-141.

188. (ps) Dialekty zatím televizi odolávají. Lidové noviny 214, 17, 13. 9. 2004, př́loha Život na Moravě, II.

\section{5}

189. (č) Dobrodružství dialektologie: bur, burák, burášek, ořech, oř́šek. Naše řeč 98, 2015, 71-78. 190. (č) Nářeční atlasy slovanských jazyků: historie a současnost. In: SiERociuk, Jerzy, ed. 2015. Gwary Dziś 7, 43-55. Dostupné z: http://DOI 10.14746/GD.2015.7.6.

191. (č) K lidové etymologii v nářečích. In: BALLEkovÁ, Katarína - KRÁLík, L'ubor - MúcskovÁ, Gabriela, eds. 2015. Jazykovedné štúdie, XXXII. Prirodzený vývin jazyka a jazykové kontakty. Bratislava: Veda, 70-76.

\section{6}

192. (č) Slovník nářečí českého jazyka - úskalí lexikografické a dialektologické abstrakce. In: LišKovÁ, Michaela - VodrážKová, Veronika - DĚngeová, Zuzana, eds. 2016. Akademický slovník současné češtiny a software pro jeho tvorbu aneb Slovníky a jejich uživatelé $v$ 21. století. Sborník abstraktů z workshopu konaného ve dnech 29.-30. 11. 2016 v Praze. Praha: Ústav pro jazyk český AV ČR, v. v. i., 38-39.

193. (č) Ke koncepci celonárodního nářečního slovníku. In: Myznikov, Sergej, ed. 2016. Slavjanskaja dialektnaja leksikografija 2. Vol. 2. Sankt-Peterburg: Nestor-Istorija, 100-116.

194. (h) Dialekt. In: Karlík, Petr - Nekula, Marek - Pleskalová, Jana, eds. 2016. Nový encyklopedický slovník češtiny. Praha: Nakladatelství Lidové noviny, 333-334. Též: Nový encyklopedický slovník češtiny online: http://www.czechency.org.

195. (h) Dialektologie. In: KARLík, Petr - NEkulA, Marek - Pleskalová, Jana, eds. 2016. Nový encyklopedický slovník češtiny. Praha: Nakladatelství Lidové noviny, 335. Též: Nový encyklopedický slovník češtiny online: http://www.czechency.org.

196. (h) Dotazník. In: Karlík, Petr - Nekula, Marek - Pleskalová, Jana, eds. 2016. Nový encyklopedický slovník češtiny. Praha: Nakladatelství Lidové noviny, 377-378. Též: Nový encyklopedický slovník češtiny online: http://www.czechency.org.

197. (h) Enkláva českého jazyka. In: KARLík, Petr - NEkulA, Marek - PlesKALová, Jana, eds. 2016. Nový encyklopedický slovník češtiny. Praha: Nakladatelství Lidové noviny, 421424. Též: Nový encyklopedický slovník češtiny online: http://www.czechency.org. (spolu s Janem Balharem a Milenou Šipkovou)

198. (h) Izoglosa. In: Karlík, Petr - Nekula, Marek - Pleskalová, Jana, eds. 2016. Nový encyklopedický slovník češtiny. Praha: Nakladatelství Lidové noviny, 719. Též: Nový encyklopedický slovník češtiny online: http://www.czechency.org.

199. (h) Jádro nářečí. In: KARLík, Petr - NEkulA, Marek - Pleskalová, Jana, eds. 2016. Nový encyklopedický slovník češtiny. Praha: Nakladatelství Lidové noviny, 726. Též: Nový encyklopedický slovník češtiny online: http://www.czechency.org.

200.(h) Jazykovězeměpisná metoda. In: Karlík, Petr - Nekula, Marek - Pleskalová, Jana, eds. 2016. Nový encyklopedický slovník češtiny. Praha: Nakladatelství Lidové noviny, 753. Též: Nový encyklopedický slovník češtiny online: http://www.czechency.org. 
201. (h) Jazykový atlas. In: KARlík, Petr - Nekula, Marek - Pleskalová, Jana, eds. 2016. Nový encyklopedický slovník češtiny. Praha: Nakladatelství Lidové noviny, 753-755. Též: Nový encyklopedický slovník češtiny online: http://www.czechency.org.

202. (h) Jazykový zeměpis. In: Karlík, Petr - Nekula, Marek - Pleskalová, Jana, eds. 2016. Nový encyklopedický slovník češtiny. Praha: Nakladatelství Lidové noviny, 771. Též: Nový encyklopedický slovník češtiny online: http://www.czechency.org.

203. (h) Karpatismy v českém lexiku. In: Karlík, Petr - Nekula, Marek - Pleskalová, Jana, eds. 2016. Nový encyklopedický slovník češtiny. Praha: Nakladatelství Lidové noviny, 785. Též: Nový encyklopedický slovník češtiny online: http://www.czechency.org.

204. (h) Moravská krátkost. In: KARLÍk, Petr - Nekula, Marek - PleSKalová, Jana, eds. 2016. Nový encyklopedický slovník češtiny. Praha: Nakladatelství Lidové noviny, 1073-1074. Též: Nový encyklopedický slovník češtiny online: http://www.czechency.org. (spolu s Janem Balharem)

205. (h) Nářeční hranice. In: KARlík, Petr - Nekula, Marek - Pleskalová, Jana, eds. 2016. Nový encyklopedický slovník češtiny. Praha: Nakladatelství Lidové noviny, 1115. Též: Nový encyklopedický slovník češtiny online: http://www.czechency.org.

206. (h) Nářečí přechodové. In: KARLík, Petr - NEkulA, Marek - PleskAlová, Jana, eds. 2016. Nový encyklopedický slovník češtiny. Praha: Nakladatelství Lidové noviny, 1464-1465. Též: Nový encyklopedický slovník češtiny online: http://www.czechency.org.

207. (h) Proteze. In: Karlík, Petr - Nekula, Marek - Pleskalová, Jana, eds. 2016. Nový encyklopedický slovník češtiny. Praha: Nakladatelství Lidové noviny, 1439-1440. Též: Nový encyklopedický slovník češtiny online: http://www.czechency.org. (spolu s Radoslavem Večerkou a s Dušanem Šlosarem)

208. (h) Nářeční skupina. In: KARLík, Petr - Nekula, Marek - PleskAlová, Jana, eds. 2016. Nový encyklopedický slovník češtiny. Praha: Nakladatelství Lidové noviny, 1115-1116. Též: Nový encyklopedický slovník češtiny online: http://www.czechency.org.

209. (h) Východomoravská nářeční skupina. In: KARLík, Petr - NEKULA, Marek - PlESKALOvÁ, Jana, eds. 2016. Nový encyklopedický slovník češtiny. Praha: Nakladatelství Lidové noviny, 2037-2040. Též: Nový encyklopedický slovník češtiny online: http://www. czechency.org.

210. (ps) Jak se kde ř́́kalo angreštu? In: Pravdová, Markéta, ed. 2016. Čeština nově od A do Ž. Praha: Academia, 15.

211. (ps) Jak se kde říkalo bramboru? In: PrAvdová, Markéta, ed. 2016. Čeština nově od A do Ž. Praha: Academia, 19.

212. (ps) Jak se kde ř́íkalo cibuli? In: PravdovÁ, Markéta, ed. 2016. Čeština nově od A do Ž. Praha: Academia, 23.

213. (ps) Jak se kde říkalo čmelákovi? In: Pravdová, Markéta, ed. 2016. Čeština nově od A do Ž. Praha: Academia, 27.

214. (ps) Jak se kde ř́íkalo dvojčatům? In: Pravdová, Markéta, ed. 2016. Čeština nově od A do Ž. Praha: Academia, 31.

215. (ps) Kde se tramvaji ř́kalo elektrika? In: Pravdová, Markéta, ed. 2016. Čeština nově od A do Ž. Praha: Academia, 35. 
216. (č) Nebot nic se tak nezapomíná jako nářečí (František Bartoš). Acta musealia Muzea jihovýchodní Moravy ve Zlíně a Muzea regionu Valašsko, Vsetín XV, 2017, 1-2, 104-114.

217. (č) Zur Homonymie im Wörterbuch der Dialekte der tschechischen Sprache. In: JANYšKOVÁ, Ilona - KARLíkovÁ, Helena - BOčEK, Vít, eds. 2017. Etymological Research into Czech. Praha: Nakladatelství Lidové noviny, 207-214.

218. (č) Ein neues dialektologisches Projekt des Tschechischen: Das Wörterbuch der tschechischen Dialekte in Böhmen, Mähren und Schlesien. In: WANDL-Vogt, Eveline Dorn, Amelie, eds. 2017. dialekt/dialect 2.0. Langfassungen / Long Papers. 7. Kongress der Internationalen Gesellschaft für Dialektologie und Geolinguistik (SIDG) / VIIth Congress of the International Society for Dialectogy and Geolinguistics (SIDG). Wien: Praesens Verlag, 213-220.

219. (pp) Existují ještě dnes tradiční dialekty? In: Rusınová, Eva, ed. 2017. Přednášky a besedy z L. běhu LŠSS. Brno: Masarykova univerzita, 138-143.

220. (r) Monografie o současné češtině. (MináŘová, Eva - Tušková, Jana Marie et al. Čeština v pohybu. Kapitoly ke zkoumání jejího stavu a proměn. Brno: Masarykova univerzita, 2015. 153 s). Naše řeč 100, 2017, 1, 46-51.

\section{8}

221. (k) Slovník nářečí českého jazyka: má nám ještě dnes co říci? In: BLÁHA, Ondřej - SvoBoDová, Jindřiška, eds. 2018. Současná jazyková situace na Moravě a ve Slezsku. Olomouc: Univerzita Palackého, 108-117.

222. (č) Není svatba jako svatba (k přeneseným pojmenováním jídel v českých nářečích). Linguistica Brunensia 66, s. 41-48.

223. (ps) Úvod. In: KLoferovÁ, Stanislava - Šipková, Milena, eds. 2018. Život ve slovech, slova $v$ životě. Procházka labyrintem českých nářečí. Praha: Nakladatelství Lidové noviny, 7-13.

224. (ps) Kostka, kostkový olej a kostkové boty. In: KLOfERovÁ, Stanislava - ŠipKová, Milena, eds. 2018. Život ve slovech, slova v životě. Procházka labyrintem českých nářeči. Praha: Nakladatelství Lidové noviny, 123-124.

225. (ps) Chléb náš vezdejší. In: KLOFERovÁ, Stanislava - ŠipkovÁ, Milena, eds. 2018. Život ve slovech, slova $v$ životě. Procházka labyrintem českých nárečí. Praha: Nakladatelství Lidové noviny, 125-135.

226. (ps) Kvasnice, droždí a hýbadla. In: KLoferová, Stanislava - Šipková, Milena, eds. 2018. Život ve slovech, slova v životě. Procházka labyrintem českých nárečí. Praha: Nakladatelství Lidové noviny, 136-138.

227. (ps) O knedlících a šiškách. In: KloferovÁ, Stanislava - ŠIPKová, Milena, eds. 2018. Život ve slovech, slova $v$ životě. Procházka labyrintem českých nářeči. Praha: Nakladatelství Lidové noviny, 139-141.

228. (ps) Škrábka s pastýřem. In: KLoferová, Stanislava - ŠIPKová, Milena, eds. 2018. Život ve slovech, slova $v$ životě. Procházka labyrintem českých náreči. Praha: Nakladatelství Lidové noviny, 153-155.

229. (ps) Sodovka a limonáda. In: KLoferovÁ, Stanislava - Šıpková, Milena, eds. 2018. Život ve slovech, slova $v$ životě. Procházka labyrintem českých nářeči. Praha: Nakladatelství Lidové noviny, 156. 
230. (ps) Kdy se podává svačina? In: KLofERovÁ, Stanislava - Šipková, Milena, eds. 2018. Život ve slovech, slova v životě. Procházka labyrintem českých nářeči. Praha: Nakladatelství Lidové noviny, 157-158.

231. (ps) Slepá bábo, kam tě vedu In: KLoferová, Stanislava - Šipková, Milena, eds. 2018. Život ve slovech, slova $v$ životě. Procházka labyrintem českých nářeči. Praha: Nakladatelství Lidové noviny, 159-162.

232. (ps) Potíže s příslovci dlouho a napřesrok. In: KLOFERová, Stanislava - ŠIPKovÁ, Milena, eds. 2018. Život ve slovech, slova v životě. Procházka labyrintem českých nárečí. Praha: Nakladatelství Lidové noviny, 172-173.

233. (ps) Pomístní jména odhalují svá tajemství. In: KLOfERová, Stanislava - Šipková, Milena, eds. 2018. Život ve slovech, slova v životě. Procházka labyrintem českých nářeči. Praha: Nakladatelství Lidové noviny, 174-181.

234. (ps) O kotovicích a Kotovicích. In: Kloferová, Stanislava - ŠipkovÁ, Milena, eds. 2018. Život ve slovech, slova $v$ životě. Procházka labyrintem českých nářeči. Praha: Nakladatelství Lidové noviny, 191-192.

235. v tisku: (k) Česká nářečí v kontaktu aneb nebyli jsme tu sami. In: JANkowiAk, Mirosław - VAŠíčEK, Michal, eds. 2020. Slovanské dialekty v jazykovém kontaktu. Nářeční lexikum $v$ pomezních oblastech $v$ minulosti a současnosti. Praha: Slovanský ústav AV ČR, v. v. i., 289-300, 354, 356-404, 410.

236. (k) Kdy žába hýbá uchem (k nářeční frazeologii). In: JANovec, Ladislav, ed. Obraz světa v jazyce a frazeologii II. Praha: Pedagogická fakulta UK.

237. v tisku: (k) Czech (jedná se o pracovní název). In: BERMEL, Neil - FELLERER, Jan, eds. The Oxford Guide to the Slavonic Languages. Part 3 Structural Overview: Variation in Slavonic Language. Oxford University Press. (spolu s Marií Krčmovou)

\title{
Elektronické publikace (nejsou zahrnuty do celkového počtu)
}

Slovník pomístních jmen na Moravě a ve Slezsku [online]. Brno: dialektologické oddělení Ústavu pro jazyk český AV ČR, v. v. i. @ 2014- [cit. 2020-07-26]. Dostupné z: http://spjms.ujc. cas.cz

Slovník nářč́ českého jazyka [online]. Brno: dialektologické oddělení Ústavu pro jazyk český AV ČR, v. v. i. ( ) 2016- [cit. 2020-07-26]. Dostupné z: http://sncj.ujc.cas.cz

\author{
Stanislava Spinková \\ Czech Language Institute of the CAS, v. v. i. \\ Veveř́ 97, 602 oo Brno \\ Czech Republic \\ spinkova@ujc.cas.cz
}


